\title{
Diversity and distribution of oligochaetes in tropical forested streams, southeastern Brazil
}

\author{
Luciana FALCI THEZA RODRIGUES,,${ }^{1 *}$ Beatriz F. JABOUR VESCOVI ROSA,${ }^{1}$ Haroldo LOBO, ${ }^{2}$ \\ Alex CAMPOS DIVINO,${ }^{3}$ Roberto DA GAMA ALVES ${ }^{1}$
}

${ }^{1}$ Laboratory of Benthic Invertebrates, Department of Zoology, Institute of Biological Sciences, Federal University of Juiz de Fora, José Lourenço Kelmer s/n, Campus Universitário, 36036-900 Juiz de Fora, Minas Gerais, Brazil; ${ }^{2}$ Nucleus of Ecotoxicology and Applied Ecology, EESC/USP, Avenida Trabalhador Sãocarlense 400, 13564-590 São Carlos, SP, Brazil; ${ }^{3}$ Environmental Management and Engineering, University of Presidente Antônio Carlos, Lincoln Rodrigues Costa 165, 365000-000 Ubá, Minas Gerais, Brazil *Corresponding author: biofalci@hotmail.com

\begin{abstract}
The distribution and beta diversity of oligochaete assemblages were investigated in different spatial scales to verify the influence of environmental factors and geographic distance on their structure. Two types of mesohabitats (riffles and pools) were sampled in eight first-order streams located in four preservation areas (Poço D'Anta Municipal Biological Reserve, Santa Cândida Municipal Biological Reserve, Ibitipoca State Park and a private farm called Fazenda Floresta) and two Atlantic Forest phytophysiognomies (Seasonal Semideciduous Forest and Rocky Field). Variations in the taxon richness, abundance and composition of the oligochaete assemblages occurred between streams and phytophysiognomies, but not between riffles and pools in the same stream. Low beta diversity values were found and both turnover and nestedness contributed similarly in the environments studied, which could have occurred because of the high capability of oligochaetes to adapt to different environmental conditions. Although the canonical correspondence analysis explained $85.5 \%$ of the data (first three axes), the partial Mantel test showed greater influence of geographic distance on the faunal composition than the environmental variables measured. Simple linear regression confirmed this result and showed that the decay of similarity increased with distance between streams. The information from this study sheds light on how environmental and spatial factors determine the variation in the distribution and diversity of oligochaetes in forested low-order streams.
\end{abstract}

Key words: Beta diversity, habitat heterogeneity, mesohabitats, distance, preserved areas, lotic environments.

Received: May 2014. Accepted: January 2015.

\section{INTRODUCTION}

Aquatic Oligochaeta (Annelida, Clitellata) is a diverse and abundant group, which occur in a diversity of waterbodies, with important participation in nutrient cycling and energy flow processes (Pelegri and Blackburn, 1995; Vorobyev et al., 2010). Besides this, some species are sensitive to changes in the water chemistry (Yap et al., 2006) and are often used in biomonitoring studies (Kazanci and Girgin, 1998; Ferreira et al., 2011).

The distribution of oligochaetes and other invertebrates in forested streams is influenced by the entry of leaves, twigs, branches and other plant components, which accumulate in streambeds forming litter patches (Allan, 1995). Many aquatic oligochaete species feed on detritus and periphyton (Smith and Kaster, 1986), so litter is a rich food source. Additionally, the litter patches serve as refuge against predators and increase the bottom area that can be colonized.

Variations in water speed contribute to the spatial heterogeneity of streams, through the formation of erosional and depositional areas (Beisel et al., 1998) and can also influence the distribution and the abundance of oligochaetes in streams (Verdonschot, 2001). The characteristics of these areas influence the distribution of food and the availability of dissolved oxygen, and hence on the composition and the distribution of invertebrates (Allan, 1995). However, while the effect of physical differences between riffle and pool mesohabitats, such as water speed, depth and substrate particle size, are well known for many invertebrates in streams, especially insects (Logan and Brooker, 1983; Vinson and Hawkins, 1998; Baptista et al., 2001; Rosa et al., 2011), the influences on the structure and distribution of oligochaetes are still little known. Besides local characteristics, factors related to the broader spatial scale (landscape) can influence the environmental characteristics on the smaller scale of the habitat (such as habitat patches), resulting in a hierarchical relationship of the environmental variables on multiple spatial scales (Heino, 2009). This pattern, together with the dispersal capacity of the species (Timm, 1980; Milbrink, 1999) and types of resources used by them (Ragonha and Takeda, 2014), determines how the composition of assemblages varies between habitats and landscapes. Therefore, environmental factors related to differences in altitude, geo- 
graphic distance and vegetation, for example, should influence the environmental characteristics of small streams and the composition of aquatic oligochaetes (Prenda and Gallardo, 1992). Species with high dispersal ability may be present in all places and greater similarity in community composition is expected (Thompson and Townsend, 2006). Although many species of aquatic oligochaetes present a wide geographic distribution (Martin et al., 2008), they do not have a good ability of disperse, (compared to aquatic insects, for example), so differences in their richness and composition can be related to the distance between sites, besides smaller scale environmental characteristics such as substrate types and water flow variations (Verdonschot, 1999, 2001; Alves et al., 2008).

Because of the lack of studies about the ecological processes responsible for the diversity and distribution of aquatic oligochaetes considering different habitat spatial scales, our objective in this study was to verify how different mesohabitats (litter in riffles and in pools), geographic distance between streams and type of phytophysognomy (seasonal semideciduous forest and rocky field), as well as their interaction, can influence variations in the composition (beta diversity) and structure of the assemblage of oligochaetes in low-order streams. We expected to find greater variation in the fauna composition (beta diversity) between streams located farther apart and in different phytophysiognomies. We also expected to find greater similarity in the fauna structure between the same type of habitat (riffles or pools) in different streams than between different habitats (riffles and pools) of a single stream.

\section{METHODS}

\section{Study area}

The study was carried out in four forested areas in southeastern Brazil, inserted in the Atlantic Forest biome considered a hotspot: Particular area- Fazenda Floresta $\left(21^{\circ} 43^{\prime}\right.$ to $21^{\circ} 44^{\prime} \mathrm{S}$ and $43^{\circ} 16^{\prime}$ to $\left.43^{\circ} 17^{\prime} \mathrm{W}\right)$; Poço D'Anta Municipal Biological Reserve $\left(21^{\circ} 44^{\prime}\right.$ to $21^{\circ} 45^{\prime} \mathrm{S}$ and $43^{\circ} 18^{\prime}$ to $\left.43^{\circ} 19^{\prime} \mathrm{W}\right)$; Santa Cândida Municipal Biological Reserve (21 ${ }^{\circ} 41^{\prime}$ to $21^{\circ} 42^{\prime} \mathrm{S}$ and $43^{\circ} 20^{\prime}$ to $\left.43^{\circ} 21^{\prime} \mathrm{W}\right)$ and Ibitipoca State Park $\left(21^{\circ} 40^{\prime}\right.$ to $21^{\circ} 43^{\prime}$ 'S and $43^{\circ} 52^{\prime}$ ' to $43^{\circ} 54^{\prime} \mathrm{W}$ ). The first two areas are connected to a forested corridor and are about $10 \mathrm{~km}$ from the Santa Cândida Municipal Biological Reserve, all located in area of the Seasonal Semideciduous Forest phytophysognomy and located in the Paraíba do Sul river basin. The Ibitipoca State Park, about $60 \mathrm{~km}$ away from the other three preserved areas, lies in an area with high altitude (more than $1250 \mathrm{~m}$ above the ocean level) that is a water divisor between two important water basin from Brazilian southeast (Rio Grande and Paraíba do Sul river basins). It has predominance of Rocky Fields and some Seasonal Semide- ciduous Forest areas (IBGE, 1991; Salimena-Pires, 1997). Eight first-order streams were sampled, all with well-preserved riparian vegetation (for the characteristics of each stream see Rodrigues et al., 2013).

\section{Sampling}

The streams were sampled during the dry season, in May, June, July and September 2010 and June 2011. We choose this period due to the greater spatial separation of the riffles and pools because of the smaller water flow, facilitating the visualization of the mesohabitats during the sampling. Along each stream we obtained samples of the submerged litter from 10 riffles and 10 pools with a Surber sampler (area of $0.04 \mathrm{~m}^{2}$, mesh of $0.21 \mathrm{~mm}$ ). The litter collected was fixed in a $4 \%$ formaldehyde solution and sorted under a stereoscopic microscope. After drying the litter, its components (whole leaves, leaf fragments, trunks, branches and seeds/fruits) were separated and weighed on a precision scale $(0.1 \mathrm{mg})$.

The list of all oligochaete species collected was published in a previous work (Rodrigues et al., 2013). In the present work we excluded the Megadrili from the analysis since it is a nomen nudum; Pristina minuta is a synonymy of Pristina osborni and Aulophorus, subgenus of Dero, is now considered genus. The organisms were identified to different taxonomic levels, so in the statistical analyses we used the Operational Taxonomic Units (OTU) system, which considers different organisms as belonging to a single taxon, independent of the level of identification (family, genus or species) (Silveira et al., 2003). In each stream, three measurements of the abiotic variables were carried out longitudinally along the collection segment. The variables measured were water temperature, dissolved oxygen, $\mathrm{pH}$ and electrical conductivity, with a Horiba U-10 multiparameter meter. Water samples were also obtained from all the sites and taken to the laboratory for analysis of total nitrogen and total phosphorous (Valderrama, 1981). Three sediment samples were obtained randomly from each stream segment for characterization of granulometry and organic matter content according to NBR 7181/84 and NBR 13600/96 (ABNT, 1984, 1996). We collected only three samples because the sediment was very homogeneous along the stretch. The depth and the width were measured with graduated ruler, the water flow was calculated by the float method (Martinelli and Krusche, 2007) and the geographic coordinates were obtained with a GPS Garmin MAP 76CSX.

\section{Data analysis}

After checking the data for normality and homogeneity (Levene test, $\mathrm{P}>0.05$ ), analysis of variance (factorial ANOVA) was applied to test the effect of the mesohabitats, streams and phytophysognomy, as well as the effect 
of the interactions of these factors, on the abundance, richness and alpha and beta diversity, using the Statistica 7 program (Statsoft, 2004). Analysis of similarity (Anosim) was used to check differences in species composition between the two mesohabitats as well as to verify differences in the litter composition between riffles and pools, considering the weight of each plant components. This analysis was carried out with the Vegan (Oksanen et al., 2011) package of the R program (R Development Core Team, 2011).

The Sorensen index ( $\beta$ sor) was employed to analyze the beta diversity between streams, mesohabitats and phytophysiognomies, based on the species abundance data. This index helps understand the influence of ecological processes (turnover and nestedness) related to spatial variation on the composition of the species at the sites studied. The index is partitioned into two additive components: spatial turnover, measured by the Simpson index ( $\beta$ sim), and nestedness ( $\beta$ nes), measured by the difference between the Sorensen and Simpson indices (Baselga, 2010). Turnover is a measure of the substitution of species between sites as a consequence of the effect of spatial or environmental factors and historic processes (Qian et al., 2005), while nestedness occurs when communities in places with a lower number of species correspond to subsets of species in places with greater richness, reflecting a process of losing or gaining species (Ulrich and Gotelli, 2007). For this analysis, we used the Betapart (Baselga et al., 2013) package of the $\mathrm{R}$ program (R Development Core Team, 2011). Finally, we compared the values generated for turnover and nestedness by simple analysis of variance (ANOVA) to check which of the two components contributed most to the variation in the composition of oligochaetes between the streams, mesohabitats and phytophysiognomies.

The association of the taxa with the environmental variables of the streams was investigated by canonical correspondence analysis (CCA) using the Monte Carlo test to establish the significance of the axes (999 permutations). For this analysis, the abundance data from the principal matrix were $\log$-transformed $[\log (x+1)]$ and the matrix of environmental data was adjusted by the standard deviation. The variables used in the CCA were those that presented factor loading greater than 0.7 in the principal component analysis (PCA), carried out previously with all the physical and chemical variables, granulometry, organic matter and litter components. This analysis was performed with the PC-Ord 5.10 program (McCune and Mefford, 2006). The partial Mantel test was used to discover which factor (environmental variables or geographic distance, calculated from the geographic coordinates in UTM) had the strongest influence on the fauna. Linear regression analysis was used to test whether higher beta diversity values could be found with increas- ing geographic distance between the streams. For this analysis, we used the beta diversity values for each stream based on the quantitative Chao index (Chao et al., 2005). This index is relatively independent of the richness and is accurate even with a small number of samples (Soininen et al., 2007). The beta diversity from the Chao index and the distance matrix were calculated with the Vegan (Oksanen et al., 2011) package of the R program (R Development Core Team, 2011) and the regression was performed with the Statistica 7 program (Statsoft, 2004).

\section{RESULTS}

All the streams had high oxygen content, low conductivity and alkaline $\mathrm{pH}$. The lowest organic matter levels were found, in streams II and III of Floresta and streams I and II of Ibitipoca State Park. The temperature $(\mathrm{F}=49.550 ; \mathrm{P}<0.01)$, oxygen $(\mathrm{F}=4.907 ; \mathrm{P}=0.004)$ and $\mathrm{pH}$ $(\mathrm{F}=3.351 ; \mathrm{P}=0.021)$ were different among the streams (Tab. 1). With respect to the litter composition (Tab. 2), the analysis of similarity showed a tiny difference (low value of R) between riffles and pools of the following streams: Floresta I (Anosim $\mathrm{R}=0.207, \mathrm{P}=0.011$ ); Santa Cândida (Anosim $\mathrm{R}=0.210, \mathrm{P}=0.012$ ); and Ibitipoca I (Anosim $\mathrm{R}=0.269, \mathrm{P}=0.008$ ). All told we collected 4310 specimens, belonging to the families Naididae (subfamilies Naidinae, Pristininae, Tubificinae and Rhyacodrilinae) and Enchytraeidae. Pristina biserrata was found only in riffles from the stream Floresta II and while Aulophorus furcatus and Dero (Dero) sp. were found only in pools from the same stream, all with low abundance (Tab. 3). The highest abundances were found in Santa Cândida and Floresta III streams, due mainly the high abundance of Nais variabilis and Enchytraeidae in Santa Cândida and of Nais communis in Floresta III. The highest richness was found in Floresta II stream, which, along with Floresta I stream, presented the highest alpha diversity values (Tab. 4).

Unlike our hypothesis that the structure of oligochaetes would differ between riffles and pools of a single stream, the abundance, richness and alpha diversity did not differ between the two mesohabitats. Besides this, the ANOVA results did not show any effect of the interaction between mesohabitat and stream and between mesohabitat and phytophysognomy on the variables described above. The analysis of similarity showed that the composition of oligochaetes was slightly different only the mesohabitats from Santa Cândida stream (Anosim $\mathrm{R}=0.175 ; \mathrm{P}=0.003$ ), probably due the high abundance of $N$. variabilis and Enchytraeidae found in riffles compared with that found in pools. However, differences between streams and phytophysiognomies were observed, along with the effect of the interaction between these two factors on the abundance, the richness and the alpha diversity (Tab. 5). Considering the beta diversity, the Sorensen index values did 

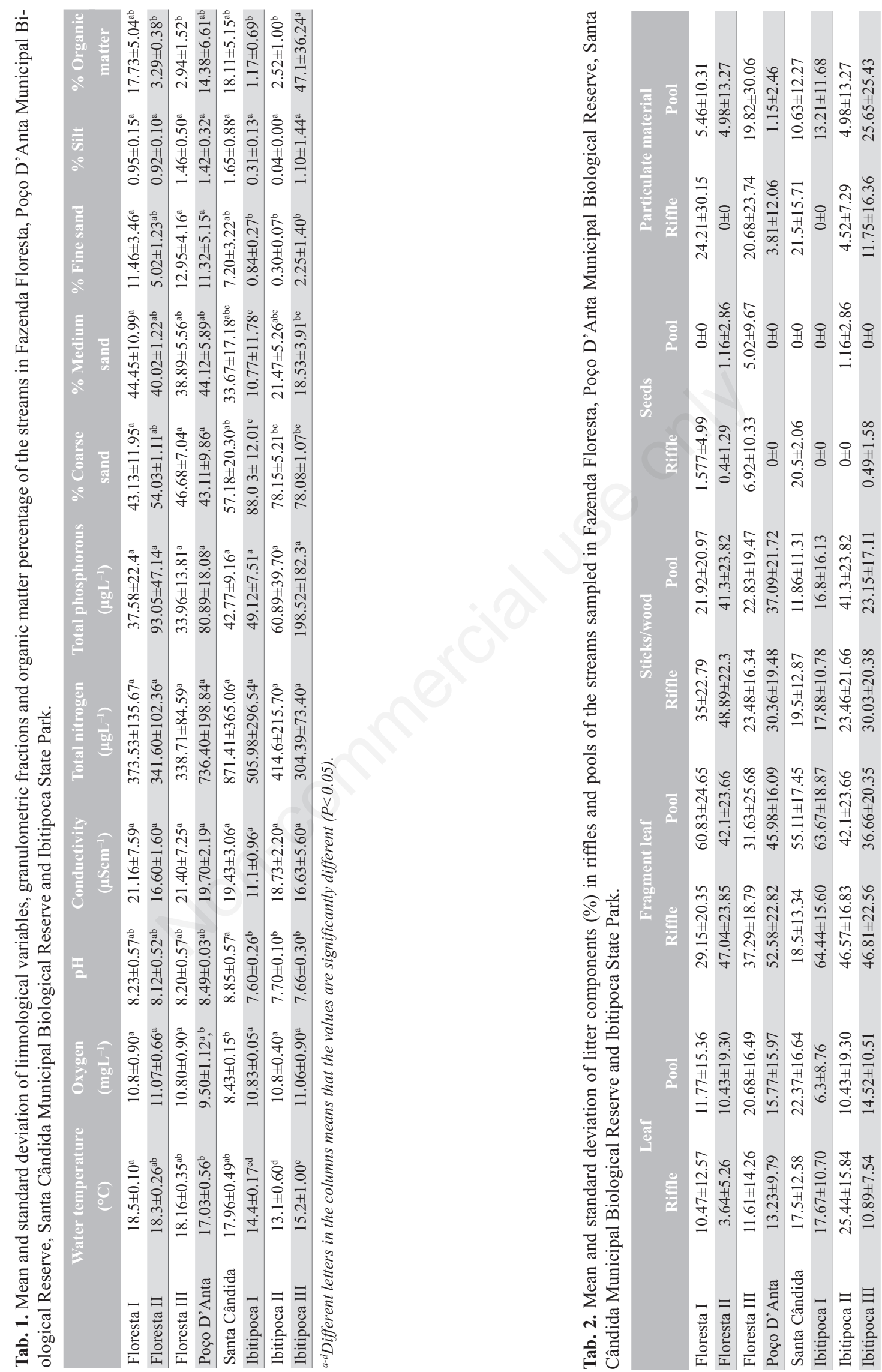
vary significantly only between riffles and pools, in a single stream, only in Santa Cândida and Ibitipoca III, and no significant variation was observed in the others streams. Contrary to our expectation, significant variations did occur between the same mesohabitat of different streams, as can be seen in Fig. 1. The turnover and nestedness components contributed similarly to the beta diversity found for the mesohabitats of the majority of the streams (six of the eight streams studied), but there was a greater tendency for turnover of the oligochaete species between riffles and pools of Floresta III stream $(\mathrm{F}=21.003, \mathrm{df}=2, \mathrm{P}<0.01)$, while nestedness had the greatest influence on the variation of the species composition between riffles and pools of Ibitipoca III stream ( $\mathrm{F}=34.354, \mathrm{df}=2, \mathrm{P}<0.01)$. Low beta diversity values for the streams were generated by the Sorensen index. The contribution of the turnover and nestedness components was similar, with the exception of Ibitipoca III stream, in which the variation in the composition of oligochaetes was more strongly influenced by the nestedness of species ( $\mathrm{F}=12.076, \mathrm{df}=7, \mathrm{P}<0.01)$ (Fig. 2). No differences in beta diversity were detected between the phytophysiognomies. The composition of oligochaetes was influenced both by the turnover and nestedness of species (Fig. 3). The first three axes of the CCA explained $43.0 \%$ (axis 1), $22.3 \%$ (axis 2) and $20.2 \%$ (axis 3 ) of the total variance of the data (cumulative total $=85.5 \%$ ). The environmental variables most strongly related to axis 1 were the granulometric fraction, temperature and altitude,

Tab. 3. Numerical abundance of the taxa collected in riffle $(\mathrm{R})$ and pool $(\mathrm{P})$ mesohabitats in each stream.

\begin{tabular}{|c|c|c|c|c|c|c|c|c|c|c|c|c|c|c|c|c|}
\hline & \multicolumn{2}{|c|}{$\begin{array}{c}\text { Floresta } \\
\text { I }\end{array}$} & \multicolumn{2}{|c|}{$\begin{array}{c}\text { Floresta } \\
\text { II }\end{array}$} & \multicolumn{2}{|c|}{$\begin{array}{c}\text { Floresta } \\
\text { III }\end{array}$} & \multicolumn{2}{|c|}{$\begin{array}{c}\text { Poço } \\
\text { D'Anta }\end{array}$} & \multicolumn{2}{|c|}{$\begin{array}{c}\text { Santa } \\
\text { Cândida }\end{array}$} & \multicolumn{2}{|c|}{$\begin{array}{c}\text { Ibitipoca } \\
\text { I }\end{array}$} & \multicolumn{2}{|c|}{$\begin{array}{c}\text { Ibitipoca } \\
\text { II }\end{array}$} & \multicolumn{2}{|c|}{$\begin{array}{c}\text { Ibitipoca } \\
\text { III }\end{array}$} \\
\hline & $\mathbf{R}$ & $\mathbf{P}$ & $\mathbf{R}$ & $\mathbf{P}$ & $\mathbf{R}$ & $\mathbf{P}$ & $\mathbf{R}$ & $\mathbf{P}$ & $\mathbf{R}$ & $\mathbf{P}$ & $\mathbf{R}$ & $\mathbf{P}$ & $\mathbf{R}$ & $\mathbf{P}$ & $\mathbf{R}$ & $\mathbf{P}$ \\
\hline \multicolumn{11}{|l|}{ NAIDIDAE } & \multicolumn{5}{|c|}{ Naidinae } & \\
\hline $\begin{array}{l}\text { Chaetogaster diastrophus (Gruithuisen 1828) } \\
\text { Aulophorus furcatus (Oken 1815) } \\
\text { Dero (Dero) sp. } \\
\text { Nais communis Piguet } 1906 \\
\text { Nais variabilis Piguet } 1906\end{array}$ & $\begin{array}{l}40 \\
- \\
- \\
85 \\
-\end{array}$ & $\begin{array}{l}59 \\
- \\
- \\
33 \\
-\end{array}$ & $\begin{array}{l}22 \\
- \\
- \\
- \\
-\end{array}$ & $\begin{array}{l}32 \\
4 \\
1 \\
- \\
2\end{array}$ & $\begin{array}{c}22 \\
- \\
- \\
333 \\
-\end{array}$ & $\begin{array}{c}38 \\
- \\
- \\
242 \\
-\end{array}$ & $\begin{array}{l}42 \\
- \\
- \\
10 \\
-\end{array}$ & $\begin{array}{l}39 \\
- \\
- \\
- \\
1\end{array}$ & $\begin{array}{c}4 \\
- \\
- \\
- \\
452\end{array}$ & $\begin{array}{l}16 \\
- \\
- \\
- \\
89\end{array}$ & $\begin{array}{l}- \\
- \\
- \\
-\end{array}$ & $\begin{array}{l}1 \\
- \\
- \\
- \\
-\end{array}$ & $\begin{array}{l}- \\
- \\
- \\
-\end{array}$ & $\begin{array}{l}- \\
- \\
- \\
- \\
-\end{array}$ & $\begin{array}{c}10 \\
- \\
- \\
- \\
-\end{array}$ & $\begin{array}{c}30 \\
- \\
- \\
- \\
3\end{array}$ \\
\hline \multicolumn{17}{|l|}{ Pristininae } \\
\hline Pristina (Pristina) longiseta leidyi Smith 1896 & 5 & 44 & 5 & 1 & 21 & 22 & - & - & 1 & 1 & - & 2 & - & 3 & 1 & - \\
\hline Pristina (Pristina) proboscidea Beddard 1896 & 9 & 12 & 14 & 9 & 17 & 9 & 1 & - & - & - & 1 & 1 & - & 2 & - & - \\
\hline Pristina (Pristina) aequiseta Bourne 1891 & 8 & 1 & 5 & 2 & 2 & 1 & 1 & - & 1 & 9 & - & - & - & - & - & 1 \\
\hline Pristina (Pristina) biserrata Chen, 1940 & - & - & 5 & - & - & - & - & - & - & - & - & - & - & - & - & - \\
\hline Pristina (Pristinella) osborni (Walton 1906) & 24 & 17 & 6 & 1 & 26 & 38 & 8 & 5 & 28 & 22 & 2 & 9 & - & 6 & 2 & 13 \\
\hline Pristina (Pristinella) sima (Marcus 1944) & - & - & - & - & 4 & 7 & 9 & 10 & - & - & - & - & - & - & - & 1 \\
\hline Pristina (Pristinella) jenkinae (Stephenson 1932) & 30 & 4 & 124 & 10 & 48 & 24 & 1 & - & 13 & 6 & - & - & 2 & - & 1 & 2 \\
\hline Pristina (Pristinella) sp. 1 & 83 & 67 & 23 & 57 & 44 & 17 & 4 & 16 & 2 & 1 & - & - & - & - & 2 & 2 \\
\hline Pristina (Pristinella) sp. 2 & - & - & - & - & - & - & - & - & 6 & 1 & 41 & 23 & 55 & 9 & - & - \\
\hline \multicolumn{17}{|l|}{ Rhyachodrilinae } \\
\hline \multicolumn{17}{|l|}{ Tubificinae } \\
\hline Immature Tubificinae & - & 8 & 1 & 23 & 4 & 7 & - & - & 8 & 40 & - & 86 & 1 & 8 & - & 1 \\
\hline ENCHYTRAEIDAE & 37 & 23 & 27 & 14 & 95 & 40 & 14 & 23 & 510 & 119 & 172 & 38 & 54 & 46 & 56 & 51 \\
\hline
\end{tabular}

Tab. 4. Total abundance, total richness and alpha diversity (Shannon) in each stream and in each mesohabitat.

\begin{tabular}{|c|c|c|c|c|c|c|c|c|c|}
\hline & \multicolumn{3}{|c|}{ Abundance } & \multicolumn{3}{|c|}{ Richness } & \multicolumn{3}{|c|}{ Alpha diversity } \\
\hline & Stream & Riffle & Pool & Stream & Riffle & Pool & Stream & Riffle & Pool \\
\hline Floresta I & 589 & 321 & 268 & 10 & 9 & 10 & 2.001 & 1.883 & 1.947 \\
\hline Floresta II & 392 & 233 & 159 & 14 & 11 & 13 & 1.937 & 1.594 & 1.894 \\
\hline Floresta III & 1062 & 616 & 446 & 12 & 11 & 12 & 1.611 & 1.559 & 1.634 \\
\hline Poço D'Anta & 184 & 90 & 94 & 10 & 9 & 6 & 1.618 & 1.623 & 1.454 \\
\hline Santa Cândida & 1331 & 1026 & 305 & 11 & 11 & 11 & 1.185 & 0.984 & 1.594 \\
\hline Ibitipoca I & 389 & 217 & 172 & 8 & 5 & 8 & 1.247 & 0.591 & 1.401 \\
\hline Ibitipoca II & 187 & 112 & 75 & 8 & 4 & 7 & 1.149 & 0.815 & 1.278 \\
\hline Ibitipoca III & 176 & 72 & 104 & 10 & 6 & 9 & 1.191 & 0.787 & 1.356 \\
\hline
\end{tabular}


in that order. Dissolved oxygen and organic matter were correlated with axis 3 and no environmental variables were correlated with axis 2 . Therefore, we plotted the graph in function of axes 1 and 3 .

The ordering showed that the taxa Pristina sp2, Bothrioneurum and immature Tubificinae were most closely related to the streams Ibitipoca I and II, at higher altitudes, predominance of coarse substrate and low quantity of organic matter. The presence of Enchytraeidae was not related specifically to any stream - specimens were abundant in all of them. However, this family had a stronger association with coarse sand and lower water temperature values. The other species were associated with streams with a higher quantity of medium and fine sand, higher water temperature and greater organic matter quantity. Only one specimen each of the species P. biserrata, A. furcatus and Dero sp. was found, making it impossible to associate them with any variable or stream (Fig. 4). According to the partial Mantel test, the geographic distance had a greater influence on the composition of oligochaete assemblages $(\mathrm{r}=0.4886 ; \mathrm{P}=0.0252)$ than the local environmental vari-
Tab. 5. Effect and interaction of mesohabitats, streams and phytophysiognomies on the abundance, richness and alpha diversity.

\begin{tabular}{|c|c|c|c|}
\hline & GL & F & $\mathbf{P}$ \\
\hline \multicolumn{4}{|l|}{ Abundance } \\
\hline Mesohabitat & 1 & 0.0154 & 0.8979 \\
\hline Stream & 7 & 3.7207 & 0.014 \\
\hline Phytophysiognomie & 1 & 25.605 & 0.0002 \\
\hline Mesohabitat x stream & 7 & 0.9434 & 0.5295 \\
\hline Mesohabitat x phytophysiognomie & 1 & 0.6998 & 0.5652 \\
\hline Stream x phytophysiognomie & 7 & 4.4147 & 0.0348 \\
\hline \multicolumn{4}{|l|}{ Richness } \\
\hline Mesohabitat & 1 & 1.3538 & 0.2574 \\
\hline Stream & 7 & 34.3993 & $<0.0001$ \\
\hline Phytophysiognomie & 1 & 58.9711 & $<0.0001$ \\
\hline Mesohabitat x stream & 7 & 0.3198 & 0.9219 \\
\hline Mesohabitat x phytophysiognomie & 1 & 0.0283 & 0.865 \\
\hline Stream x phytophysiognomie & 7 & 53.6316 & 0.0001 \\
\hline \multicolumn{4}{|l|}{ Alpha diversity } \\
\hline Mesohabitat & 1 & 2.0172 & 0.168 \\
\hline Stream & 7 & 22.0302 & $<0.0001$ \\
\hline Phytophysiognomie & 12 & 42.7079 & $<0.0001$ \\
\hline Mesohabitat x stream & 7 & 1.056 & 0.4724 \\
\hline Mesohabitat x phytophysiognomie & 1 & 0.7481 & 0.5803 \\
\hline Stream x phytophysiognomie & 7 & 7.3103 & 0.0096 \\
\hline
\end{tabular}

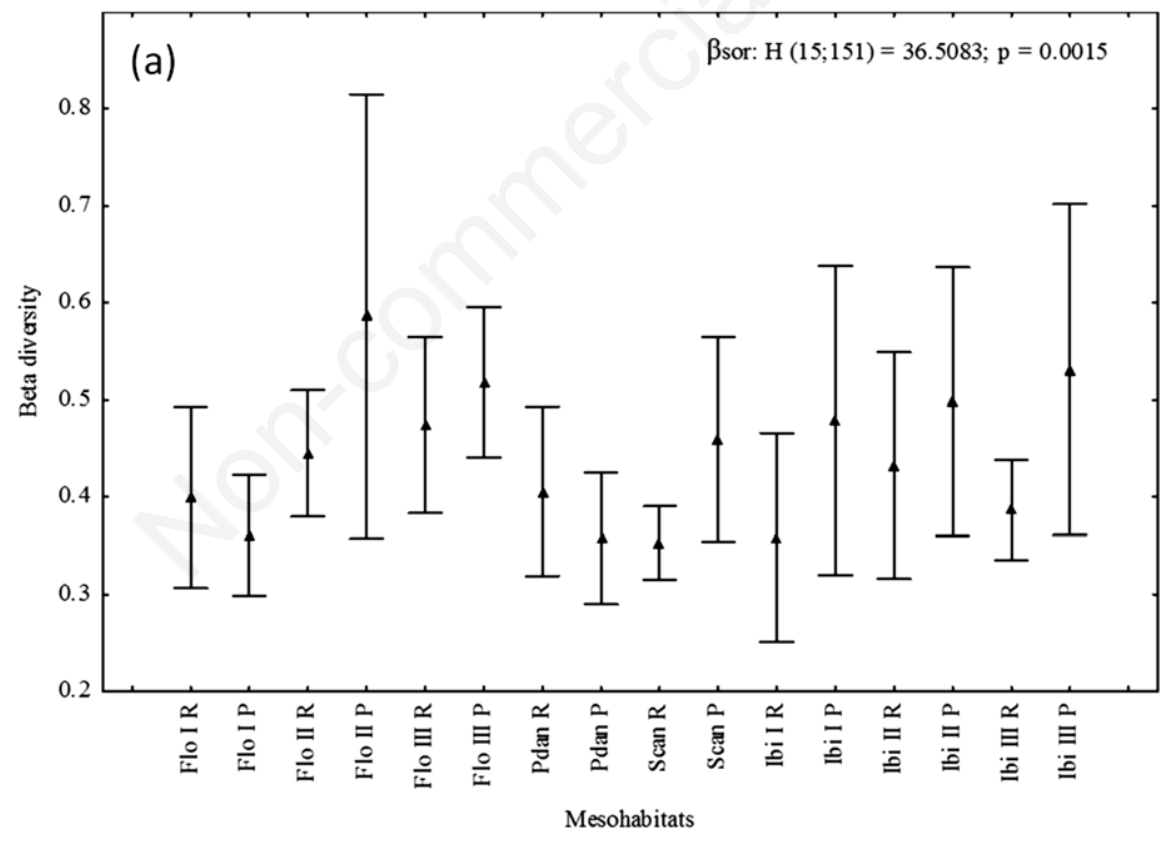

(b)

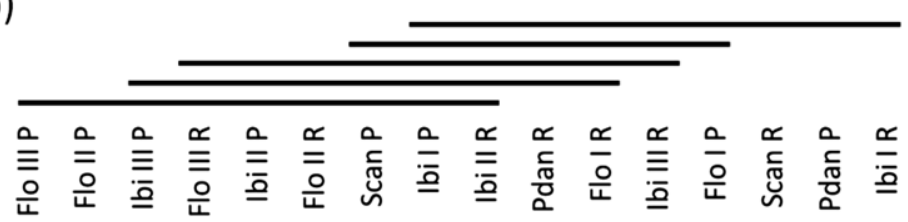

Fig. 1. a) Beta diversity of Sorensen ( $\beta$ sor) of riffles (R) and pools (P) of the streams sampled in Fazenda Floresta (Flo), Poço D'Anta Municipal Biological Reserve (Pdan), Santa Cândida Municipal Biological Reserve (Scan) and Ibitipoca State Park (Ibi); bars represent the $95 \%$ confidence interval. b) Statistical comparison of the values of beta diversity of Sorensen between the mesohabitats; sites linked by the same bar does not show significant difference $(\mathrm{P}>0.05)$. 
ables $(\mathrm{r}=0.1346 ; \mathrm{P}=0.2236)$, but the relation between distance and beta diversity was low, as shown by the regression analysis (Fig. 5).

\section{DISCUSSION}

One of our hypothesis was that we would found greater similarity in the fauna structure between the same type of habitat (riffles or pools) in different streams than between different habitats of a single stream, however, the fauna structure of riffles and pools of a single stream was similar. Previous studies have demonstrated that the richness and distribution of oligochaetes could be influenced by the substrate composition and heterogeneity (Dumnicka, 1994; Martínez-Ansemil and Collado, 1996; Schenková and Helešic, 2006; Gorni and Alves, 2012), the quality and availability of food (Learner et al., 1978; Collado and Schmelz, 2001) as well by the water flow, although there isn't a clear relation between the last variable and their distribution. (Verdonschot, 2001). In the present study, the litter composition between riffles and pools was similar in all streams and differences in the abundance were more significative. Probably the slow water speed of the riffles $\left( \pm 0.30 \mathrm{~ms}^{-1}\right)$ was not a limiting factor for the distribution of the oligochaetes in these habitats. Furthermore the similarity of the litter composition probably created similar conditions between mesohabitats of the same stream, resulting in a structure similar fauna. According Syrovátka et al. (2009) the flow conditions were less important in explaining the distribution of oligochaetes than the differences in the amount of organic matter and roughness of the substrate. On the other hand, according to the CCA results, the dissimilarity of the oligochaete assemblages between the streams was associated with the distinct environmental characteristics. The type de phytophysiognomies resulted in greater similarity of streams I and II of Ibitipoca park (flowing through rocky fields), which stood apart from stream III of this park (seasonal semideciduous forest). The streams in rocky fields have beds made up predominantly of rocks and coarse sand, with low organic matter percentage, in contrast to stream III, with more organic matter. The other streams differed from Ibitipoca streams in function of the greater

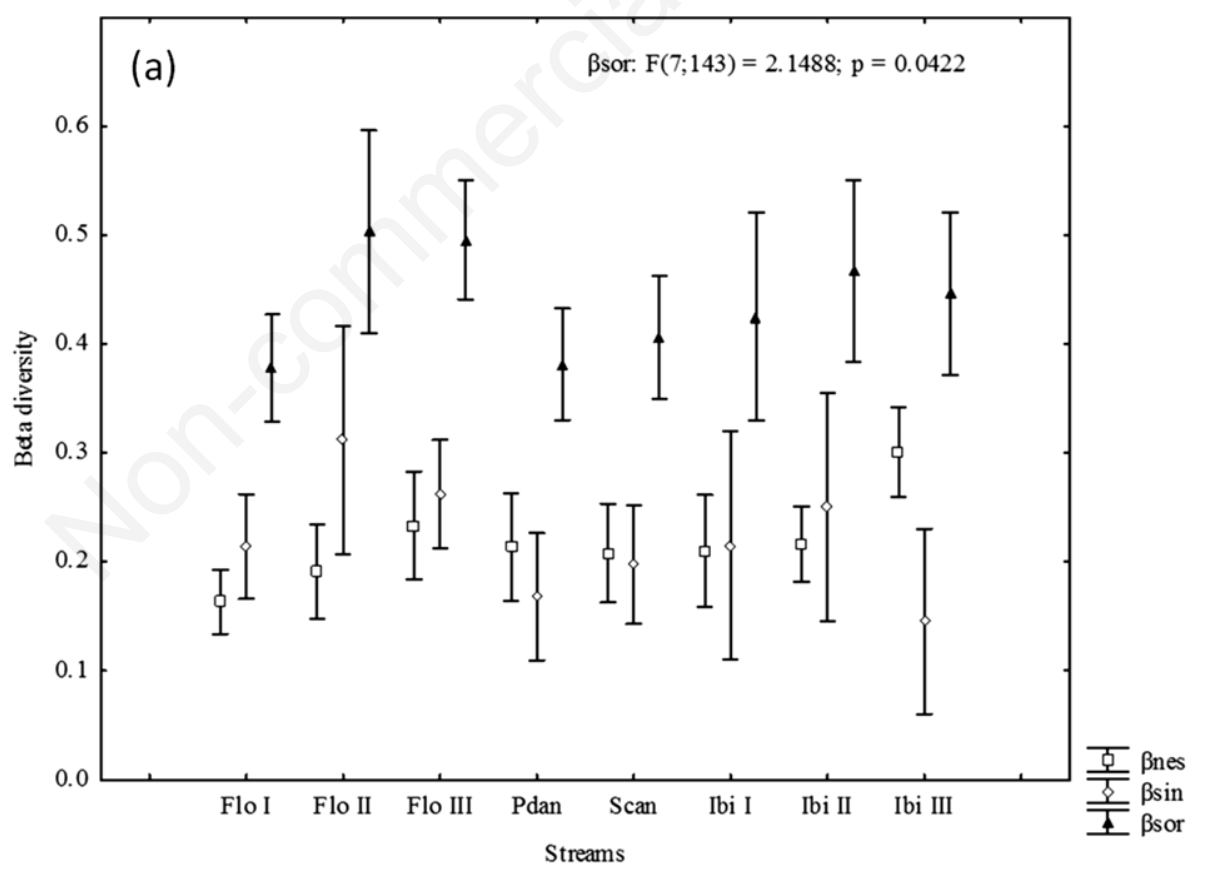

(b)

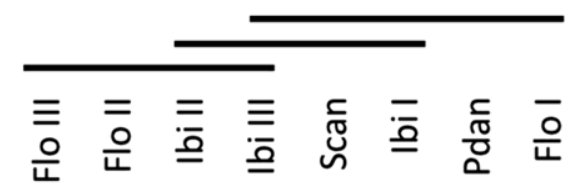

Fig. 2. a) Beta diversity of Sorensen ( $\beta$ sor) and its components (nestedness, $\beta$ nes; turnover, $\beta$ sim) for each stream sample in Fazenda Floresta (Flo), Poço D’Anta Municipal Biological Reserve (Pdan), Santa Cândida Municipal Biological Reserve (Sca) and Ibitipoca State Park (Ibi); bars represent the $95 \%$ confidence interval. b) Statistical comparison of the values of beta diversity of Sorensen among the streams; sites linked by the same bar does not show significant difference $(\mathrm{P}>0.05)$. 


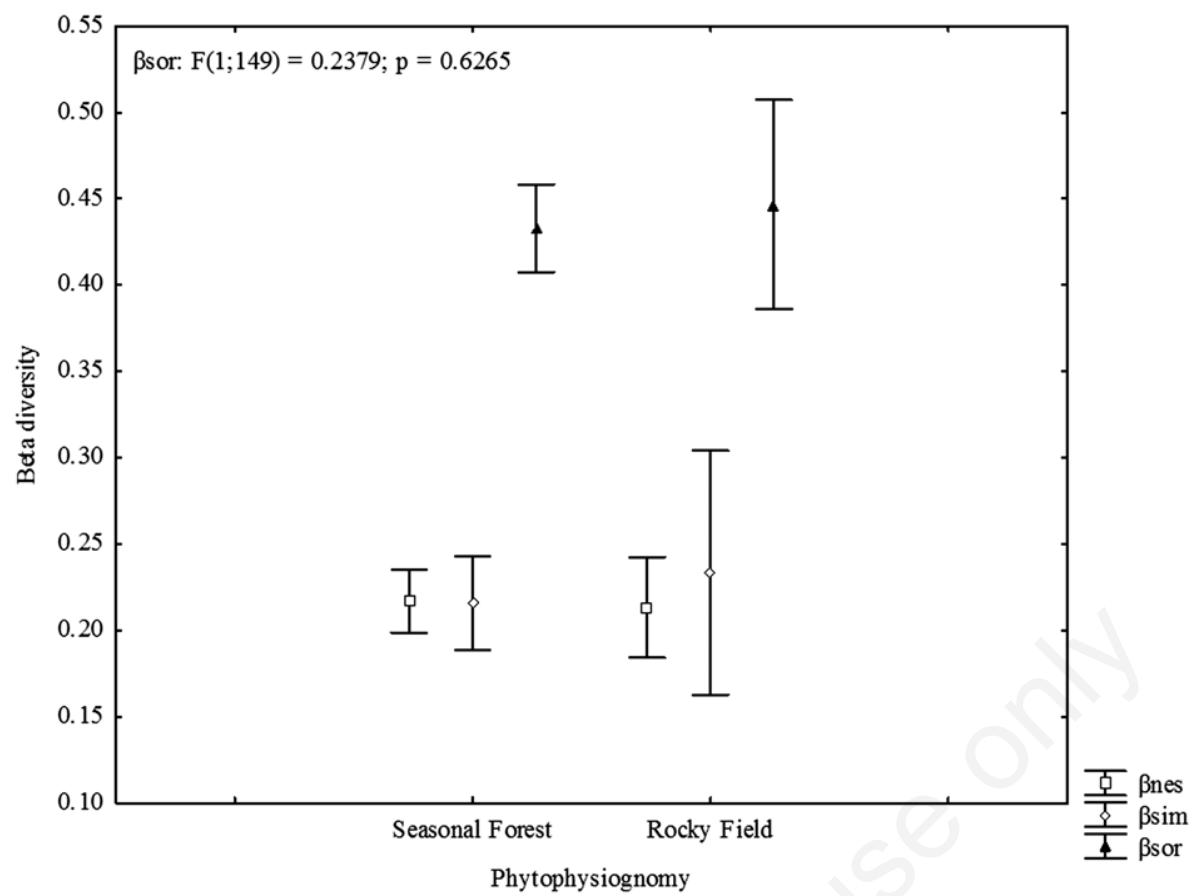

Fig. 3. Beta diversity of Sorensen ( $\beta$ sor) and its components (nestedness, $\beta$ nes; turnover, $\beta$ sim) for the two phytophysiognomies studied. The bars represent the $95 \%$ confidence interval.

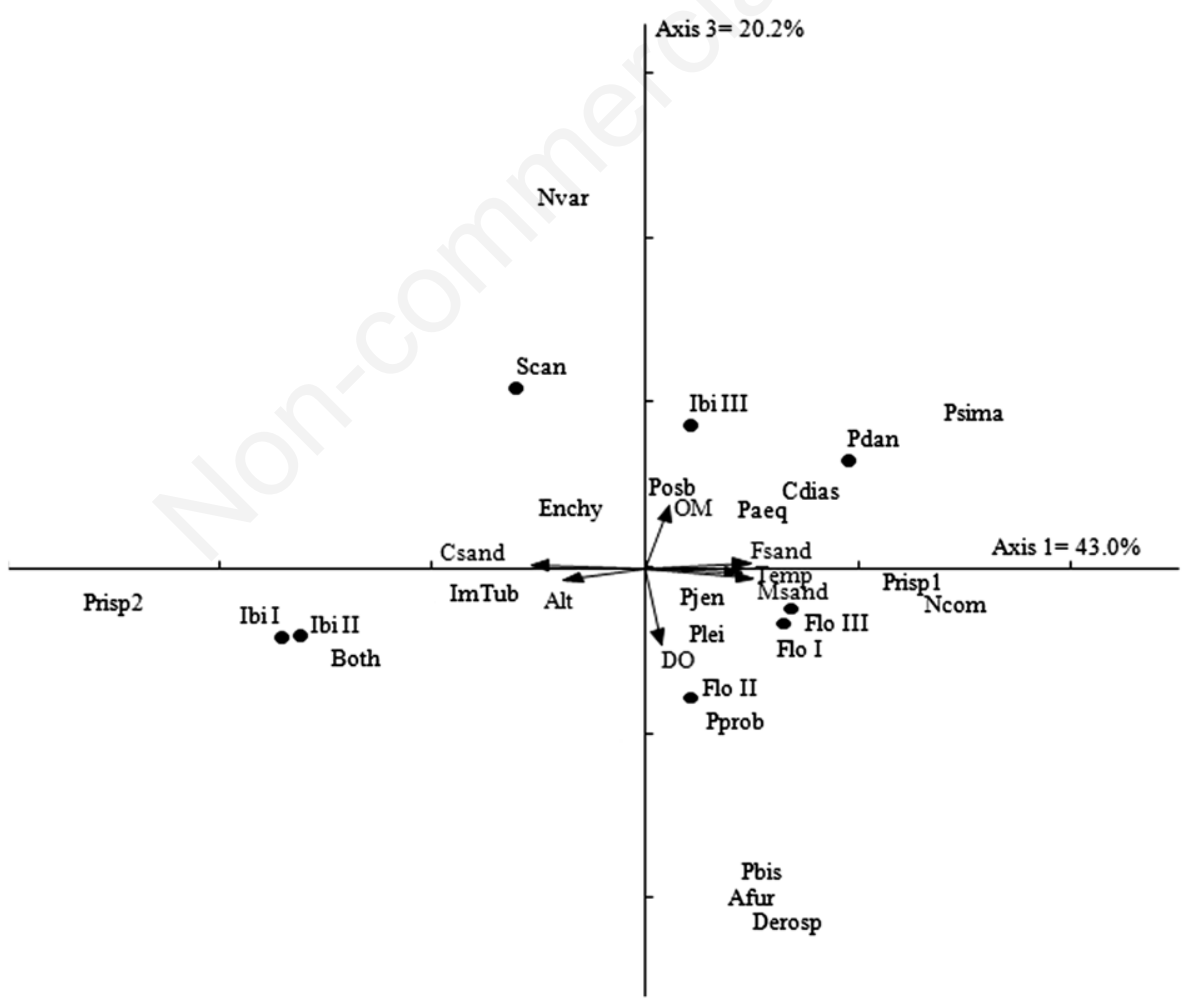

Fig. 4. Canonical correspondence analysis of the oligochaete species and environmental variables in streams of Fazenda Floresta (Flo), Poço D’Anta Municipal Biological Reserve (Pdan), Santa Cândida Municipal Biological Reserve (Sca) and Ibitipoca State Park (Ibi). Nvar, Nais variabilis; Enchy, Enchytraeidae; Posb, Pristina osborni; Paeq, Pristina aequiseta; Cdias, Chaetogaster diastrophus; Psima, Pristina sima; Pjenk, Pristina jenkinae; Plei, Pristina leidyi; Prisp1, Pristina sp1; Ncom, Nais communis; Pprob, Pristina proboscidea; ImTub, imature tubificinae; Both, Bothrioneurum; Prisp2, Pristina sp2; Pbis, Pristina biserrata; Afur, Aulophorus furcatus; Derosp, Dero (Dero) sp.; Csand, corse sand; Msand, medium sand; Fsand, fine sand; OM, organic matter; Temp, temperature; DO, dissolved oxygen; Alt, altitude. 
quantity of medium and fine sediment fractions and higher water temperature. In these streams, the species $N$. communis, Pristina sp1, P. jenkinae, P. leidyi and P. proboscidea were more abundant.

Streams that were located the furthest apart $(60 \mathrm{~km})$ did not present the highest beta diversity values. This result can possibly be explained by the weak relation found between the increase in distance and the beta diversity of oligochaetes. Both the turnover and nestedness contributed to the variations in composition, except for Ibitipoca III stream, in which the species composition was only significantly influenced by nestedness.

According to Thompson and Townsend (2006), if the dissimilarity in the species composition is influenced by limitations of dispersion, then higher species turnover than nestedness should be expected between sites. In this case, the increase in dissimilarity will have a positive relation with the distance between the sites sampled (Stevens et al., 2007). On the other hand, if the dissimilarity between sites results from selection of habitats, causing the presence or absence of species, there will be a positive correlation between the increase in dissimilarity of fauna and environmental differences between the sites, with a stronger contribution of nestedness than turnover. Probably the dispersion limitations of oligochaetes did not constitute a barrier to the species, nor did the differences in environmental variables between streams, as shown by the partial Mantel analysis. This explains the low beta diversity values found for the streams and the similar contribution of turnover and nestedness, with the exception of Ibitipoca III stream, whose environmental differences probably were a determining factor for the process of habitat selection to act on the species composition. Although the CCA grouped Floresta I, II and III streams in function of similarities of some environmental variables, Floresta III stream presented higher beta diversity than Floresta I and II streams, located in the same forest fragment, followed by Poço D'Anta stream, which is located in a nearby area, connected by a forest corridor to Fazenda Floresta. Possibly other factors not measured in this study, such as interactions of species, might have generated greater dissimilarities in the fauna of these streams. According to Chust et al. (2004), animals with low mobility normally respond more strongly to small variations in the environment, so they tend to be structured by species turnover in the landscape. Many oligochaete species are adapted to pronounced changes in environmental conditions (Gnaiger and Staudigl, 1987; Montalto and Marchese, 2005), enabling these invertebrates to colonize a wide range of environments (Prenda and Gallardo, 1992). Therefore, the high adaptive capability of oligochaetes to different environmental conditions can help explain the low beta diversity in the environments studied, considering that the taxa found in the present study have wide distribution.

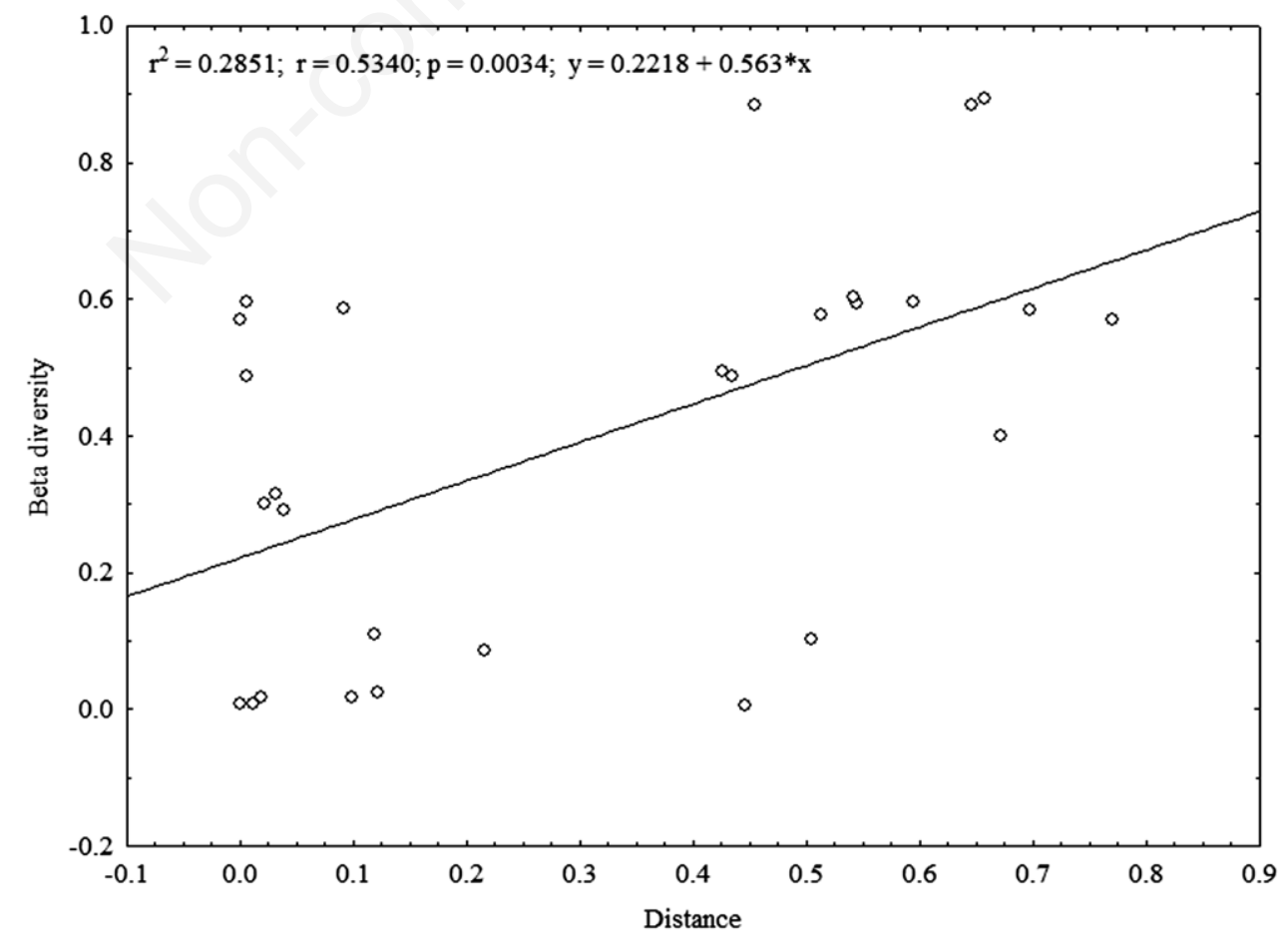

Fig. 5. Relation between beta diversity and distance of the streams studied. 
Studies analyzing the effect of environmental variables and spatial scale on the variation of the structure and distribution of benthic invertebrate species are necessary to understand the ecological processes that determine the patterns of diversity in streams. According to Nijboer et al. (2004), it is important to sample different mesohabitats within a single stream to obtain a good understanding of the distribution and true diversity of oligochaetes in these settings. Besides this, ecological studies to investigate the assemblages of invertebrates of streams in nearby and distant areas help to understand what scale best determines variations in the diversity of these organisms.

\section{CONCLUSIONS}

In this study, variations in the richness of taxa, abundance and composition of oligochaete assemblages occurred between streams but not between riffles and pools of any single stream, demonstrating a weaker effect of the mesohabitat compared to the effect of geographic distance and of phytophysognomy on the variation of the structure of the oligochaete assemblages. With respect to the beta diversity, no pattern was found, since this varied between the mesohabitats of some streams and among the streams, regardless of the differences in the phytophysiognomies and in the geographic distances between the environments.

Although the relation between similarity in the composition of invertebrate assemblages and geographic distance has been better investigated in recent years, this relation is still little known for oligochaetes. Therefore, the information in this study should help understand how environmental and spatial factors determine the variation of the richness and diversity of oligochaetes in low-order forested streams.

\section{ACKNOWLEDGMENTS}

We would like to thank Coordenação de Aperfeiçoamento de Pessoal de Nível Superior (CAPES), Conselho Nacional de Desenvolvimento Científico e Tecnológico (CNPq) (Process: 303156/2012-0) and Fundação de Amparo à Pesquisa do Estado de Minas Gerais (FAPEMIG) for support.

\section{REFERENCES}

ABNT-Associação Brasileira de Normas Técnicas, 1984. SoloAnálise granulométrica. NBR-7181.

ABNT-Associação Brasileira de Normas Técnicas, 1996. SoloDeterminação do teor de matéria orgânica por queima a $440^{\circ} \mathrm{C}$ - método de ensaio. NBR-13600.

Allan JD, 1995. Stream Ecology: Structure and function of running waters. Chapman and Hall, London: 436 pp.

Alves RG, Marchese MR, Martins RT, 2008. Oligochaeta (Annelida, Clitellata) of lotic environments at Parque Estadual Intervales (São Paulo, Brazil). Biota Neotrop. 8:21-25.

Baptista DF, Buss DF, Dorvillé LFM, Nessimian JL, 2001. Di- versity and habitat preference of aquatic insects along the longitudinal gradient of the Macaé river basin, Rio de Janeiro, Brazil. R. Bras. Biol. 61:249-258.

Baselga A, 2010. Partitioning the turnover and nestedness components of beta diversity. Global Ecol. Biogeogr. 19:134-143.

Baselga A, Orme D, Villeger S, De Bortoli J, Leprieur F, 2013. betapart: Partitioning beta diversity into turnover and nestedness components. R package version 1.3. http://CRAN.Rproject.org/package=betapart. Accessed 12 July 2014.

Beisel JN, Usseglio-Polatera P, Thomas S, Moreteau JC, 1998. Stream community structure in relation to spatial variation: the influence of mesohabitat characteristics. Hydrobiologia 389:73-88.

Chao A, Chazdon RL, Colwell RK, Shen TJ, 2005. A new statistical approach for assessing similarity of species composition with incidence and abundance data. Ecol. Lett. 8:148-159.

Chust G, Pretus JL, Ducrot D, Ventura D, 2004. Scale dependency of insect assemblages in response to landscape pattern. Landscape Ecol. 19:41-57.

Collado R, Schmelz RM, 2001. Oligochaete distribution patterns in two German hardwater lakes of different trophic state. Limnologica-Ecology and Management of Inland Waters 31:317-328.

Dumnicka E, 1994. Communities of oligochaetes in mountain streams of Poland. Hydrobiologia 278:107-110.

Ferreira WR, Paiva LT, Callisto M, 2011. Development of a benthic multimetric index for biomonitoring of a neotropical watershed. Braz. J. Biol. 71:15-25.

Gnaiger E, Staudigl I, 1987. Aerobic metabolism and physiological responses of aquatic oligochaetes to environmental anoxia: heat dissipation, oxygen consumption, feeding, and defecation. Physiol. Zool. 659-677.

Gorni GR, Alves RG, 2012. Oligochaetes (Annelida, Clitellata) in a neotropical stream: a mesohabitat approach. Iheringia Ser. Zool. 102:106-110.

Heino J, 2009. Biodiversity of aquatic insects: spatial gradients and environmental correlates of assemblage-level measures at large scales. Freshwater Rev. 2:1-29.

IBGE- Instituto Brasileiro de Geografia e Estatística, 1991. [Classificação da vegetação brasileira, adaptada a um sistema universal].[Document in Portuguese]. Rio de Janeiro: 122 p.

Kazanci N, Girgin S, 1998. Distribution of Oligochaeta species as bioindicators of organic pollution in Ankara Stream and their use in biomonitoring. Turk. J. Zool. 22:83-88.

Learner MA, Lochhead, G Hughes BD, 1978. A review of the biology of British Naididae (Oligochaeta) with emphasis on the lotic environment. Freshwater Biol. 8:357-375.

Logan P, Brooker MP, 1983. The macroinvertebrate faunas of riffles and pools. Water Res. 17:263-270.

Martin P, Martinez-Ansemil E, Pinder A, Timm T, Wetzel MJ, 2008. Global diversity of oligochaetous clitellates (Oligochaeta; Clitellata) in freshwater. Hydrobiologia 595:117-127.

Martinelli LA, Krusche AV, 2007. [Amostragem em rios, p. 263280]. In: C.E.M. Bicudo and D.C. Bicudo (eds.), [Amostragem em Limnologia. 1].[Book in Portuguese]. Rima Editora, São Carlos.

Martínez-Ansemil E, Collado R, 1996. Distribution patterns of aquatic oligochaetes inhabiting watercourses in the Northwestern Iberian Peninsula. Hydrobiologia 334:73-83. 
McCune B, Mefford MJ, 2006. PC-ORD- Multivariate analysis of ecological data, version 6.0. MjM Software Design, Gleneden Beach. Accessed on: 17 July 2014.

Milbrink G, 1999. Distribution and dispersal capacity of the PontoCaspian tubificid oligochaete Potamothrix heuscheri (Bretscher, 1900) in Scandinavia. Hydrobiologia 406:133-142.

Montalto L, Marchese M, 2005. Cyst formation in Tubificidae (Naidinae) and Opistocystidae (Annelida, Oligochaeta) as an adaptive strategy for drought tolerance in fluvial wetlands of the Paraná River, Argentina. Wetlands 25:488-494.

Nijboer RC, Wetzel MJ, Verdonschot PF, 2004. Diversity and distribution of Tubificidae, Naididae, and Lumbriculidae (Annelida: Oligochaeta) in the Netherlands: an evaluation of twenty years of monitoring data. Hydrobiologia 520:127-141.

Oksanen J, Blanchet FG, Kindt R, Legendre P, O'Hara RB, Simpson GL, Solymos P, Stevens MHH, Wagner H, 2011. Vegan: Community Ecology Package. R package ver. 2.0-2.

Pelegri SP, Blackburn TH, 1995. Effects of Tubifex tubifex (Oligochaeta: Tubificidae) on N-mineralization in freshwater sediments, measured with ${ }^{15} \mathrm{~N}$ isotopes. Aquat. Microb. Ecol. 9:289-294.

Prenda J, Gallardo A, 1992. The influence of environmental factors and microhabitat availability on the distribution of an aquatic oligochaete assemblage in a Mediterranean river basin. Int. Rev. Ges. Hydrobio. 77:421-434.

Qian H, Ricklefs RE, White PS, 2005. Beta diversity of angiosperms in temperate floras of eastern Asia and eastern North America. Ecol. Lett. 8:15-22.

R Development Core Team, 2011. R: a language and environment for statistical computing. R Foundation for Statistical Computing, Vienna, Austria. Accessed on: 17 July 2014. Available from: http://www.r-project.org/

Ragonha FH, Takeda AM, 2014. Does richness of Oligochaeta (Annelida) follows a linear distribution with habitat structural heterogeneity in aquatic sediments? J. Limnol. 73:146-156.

Rodrigues LFT, Leite FS, Alves RG, 2013. Inventory and distribution of Oligochaeta (Annelida, Clitellata) in first-order streams in preserved areas of the state of Minas Gerais, Brazil. Biota Neotrop. 3:245-254.

Rosa BFJV, Oliveira VC, Alves RG, 2011. Structure and spatial distribution of the Chironomidae community in mesohabitats in a first order stream at the Poço D'Anta Municipal biological reserve in Brazil. J. Insect Sci. 11:1-13.

Salimena-Pires FR, 1997. [Aspectos fisionômicos e vegetacionais do Parque Estadual de Ibitipoca, Minas Gerais, Brasil].[Article in Portuguese]. In: GC Rocha (ed.). Proceeding I Symp. de Pesquisa sobre o Parque Estadual de Ibitipoca. Juiz de Fora, Núcleo de Pesquisa em Zoneamento Ambiental da UFJF.

Schenková J, Helešic J, 2006. Habitat preferences of aquatic Oligochaeta (Annelida) in the Rokytná River, Czech Republic-a small highland stream. Hydrobiologia 564:117-126.
Silveira MP, Queiroz JF, Boeira RC, 2003. [Metodologia para obtenção e preparo de amostras de macroinvertebrados bentônicos em streams].[Article in Portuguese]. Accessed on: 13 March 2014. Available from: http://www.alice.cnptia.embrapa.br/handle/doc/15072.

Smith ME, Kaster JL, 1986. Feeding habits and dietary overlap of Naididae (Oligochaeta) from a bog stream. Hydrobiologia 137:197-201.

Soininen J, McDonald R, Hillebrand H, 2007. The distance decay of similarity in ecological communities. Ecography 30:3-12.

Statsoft, 2004. Statistica: data analysis software system, ver. 7. Accessed on: 17 July 2014. Available from: http:/www.statsoft.com

Stevens RD, López-González CELIA, Presley SJ, 2007. Geographical ecology of Paraguayan bats: spatial integration and metacommunity structure of interacting assemblages. J. Anim. Ecol. 76:1086-1093.

Syrovátka V, Schenková J, Brabec K, 2009. The distribution of chironomid larvae and oligochaetes within a stony-bottomed river stretch: the role of substrate and hydraulic characteristics. Fund. Appl. Limnol. 174:43-62.

Thompson R, Townsend C, 2006. A truce with neutral theory: local deterministic factors, species traits and dispersal limitation together determine patterns of diversity in stream invertebrates. J. Anim. Ecol. 75:476-484.

Timm T, 1980. Distribution of aquatic oligochaetes, p. 55-77. In: R.O. Brinkhurst and D.G. Cook (eds.), Aquatic oligochaete biology. Springer US.

Ulrich W, Gotelli NJ, 2007. Disentangling community patterns of nestedness and species co-occurrence. Oikos 116:2053-2061.

Valderrama JC, 1981. The simultaneous analysis of total nitrogen and phosphorus in natural waters. Mar. Chem. 10:109-122.

Verdonschot PFM, 1999. Micro-distribution of oligochaetes in a soft-bottomed lowland stream (Elsbeek; The Netherlands). Hydrobiologia 406:149-163.

Verdonschot PFM, 2001. Hydrology and substrates: determinants of oligochaete distribution in lowland streams (The Netherlands). Hydrobiologia 463:249-262.

Vinson MR, Hawkins CP, 1998. Biodiversity of stream insects: variation at local, basin, and regional Scales 1. Annu. Rev. Entomol. 43:271-293.

Vorobyev DS, Frank YA, Lushnikov SV, Zaloznyi NA, Noskov YA, 2010. Use of Limnodrilus hoffmeisteri (Tubificidae, Oligochaeta) for purification of bottom sediments from oil and oil products. Sib. J. Ecol. 1:21-27.

Yap CK, Rahim Ismail A, Azrina MZ, Ismail A, Tan SG, 2006. The influential of physico-chemical parameters on the distributions of oligochateas (Limnodrilus sp.) at the polluted downstream of the tropical Langat River, Peninsular Malaysia. J. Appl. Sci. Environ. Mgt. 10:135-140. 